\title{
The Measles Epidemic of 1714-1715 in New France
}

\author{
Ryan Mazan \\ Population Studies Centre \\ Department of Sociology \\ University of Western Ontario \\ London, Ontario, Canada \\ E-mail: rmazan@uwo.ca
}

\author{
Alain Gagnon \\ Population Studies Centre \\ Department of Sociology and \\ Department of Epidemiology \& Biostatistics \\ University of Western Ontario \\ London, Ontario, Canada
}

\section{Bertrand Desjardins}

Département de démographie

Université de Montréal

Montréal, Québec, Canada

\section{Abstract}

This study utilizes methods to follow a measles epidemic in New France, where cause of death information is lacking. We fit a series of splines to estimate mortality and trace the origin, spread, duration and severity of the epidemic, which originated in the region of Montreal during the $2^{\text {nd }}$ quarter of 1714. By the $3^{\text {rd }}$ quarter, the epidemic had spread throughout the colony and had run its course by the second quarter of 1715 . Overall, the measles death rate was 52.8 per 1,000 for children under age 15 and females were more likely than males to have died from the virus.

Keywords: Measles mortality, epidemic, smoothing spline, New France 


\section{Résumé}

Cette étude retrace pas à pas une épidémie de rougeole qui a eu lieu en Nouvelle-France, où les causes de décès sont manquantes. Nous estimons la mortalité par une série de splines et retraçons l'origine, la durée, et la sévérité de cette épidémie qui a commencé dans la région de Montréal dans le deuxième quart de l'année 1714. Au troisième quart de la même année, l'épidémie s'était répendue dans toute la colonie et se dissipa finalement dans le second quart de l'anrée 1715. Le quotient de mortalité associé à la rougeole est de 52,8 pour mille parmi les enfants de moins de 15 ans. Par ailleurs, il semble que les filles aient été plus durement affectées par le virus que leurs contemporains de sexe masculin.

Mots clés: Mortalité due à la rougeole, épidémies, splines, Nouvelle-France

\section{Introduction}

Spread along the Saint Lawrence Valley, the first French Canadians had a unique epidemiologic profile for the time. The ready access to subsistence resources made the colonists a healthy and robust group of individuals. Indeed the colonists were healthier than their European counterparts, as is evident by their higher life expectancy (Charbonneau et al., 2000). Early on, the population was small and sparsely dispersed over a large area making it harder and slower for viruses to penetrate the vast frontier. A low density probably protected the colony from becoming a perpetual host population of infectious diseases. However, the circumstances of the inhabitants began to change by the 18th century. The population was going through a stage of rapid growth due almost exclusively to natural increase (i.e. excess births over deaths). Québec was a high fertility population ( 9.2 children per woman married until age 45 ) and had a natural rate of increase of about $2.5 \%$ or a doubling time of approximately 30 years (Charbonneau et al., 2000).

The colonists were not isolated from outside contact with the rest of North America. Colonial America was increasing in size and due to a long sustained immigration, had a much larger population than New France. Recurring warfare with Britain and Aboriginal tribes also led to more frequent encounters with the outside world. Additionally, the fur trade opened up vast trade routes with local Aboriginal tribes, as well as those from the American Colonies and as far west as the prairies (Moore, 1997). As such, the increasing 
population density of North America, frequent conflicts and continual contact with trading partners probably led to a greater number of contact patterns through which a virus could be transmitted more efficiently than before. Epidemics began to appear with greater frequency and severity throughout the colony during the first half of the 18th century (Gagnon and Mazan, 2009). These disturbances led to many fatalities, as the lack of exposure in previous times meant that the Canadian born had no acquired immunity to infectious diseases that entered the colony.

Unlike historical Europe, mortality crises resulting from epidemics have not been extensively documented in the Canadian context. Fortunately, detailed Parish registers containing baptisms and burials are available for Québec from the outset of the European population. Because of this information, we have the potential to conduct detailed analyses on the periodic outbreaks in pre-industrial Quebec. So far, only a couple of studies have undertaken such a task (Desjardins, 1996; Dechene and Robert, 1993). The former analyzed the spread and impact of the smallpox epidemic of 1702-03 while the latter was a study on the impact of the 1832 cholera epidemic. These studies are very informative and provide insight into the origin, severity and diffusion (regional variations) of the specified epidemics. Yet, there are many undocumented epidemics such as a largely unknown measles epidemic in 1714-1715.

There is limited historical evidence of a measles epidemic in 1714 in Canada. Additionally, we do not have cause of death records for that period, which would enable us to directly identify the event as a measles epidemic. However, historical accounts from Colonial America indicate that a 'serious' measles epidemic took place between 1713 and 1715 (Duffy, 1953). The exact origin is not given, but residents of Boston, Massachusetts suffered many fatalities during the outbreak, which began in the late summer of 1713 and had run its course by the end of January 1714. By February of that year, the virus had spread to New York, New Jersey, Connecticut and Pennsylvania (Duffy, 1953). The virus probably arrived in New France a couple months later via Aboriginal traders traveling from Colonial America.

Measles is one of the most contagious diseases and has been called the 'largest child killer in history' (Clements and Hussey, 2004). It is an acute viral illness caused by a virus in the paramyxovirus family. If exposed, almost all non-immune children contract measles with approximately $99 \%$ of susceptibles contracting the virus after first contact with an infected person. Generally, the virus is spread through airborne droplets via sneezing and/or coughing. The development of an infection (the latent period) ranges from 5 to 10 days, while the infectious period lasts another 7 days (Murray and Cliff, 1977). Individuals usually do not die directly from measles, but from complications associated with the virus. Measles attacks epithelial cells and suppresses the immune system, which makes the infected individual highly susceptible to serious complications such as severe diarrhoea and pneumonia. For children, pneumonia is the most 
common cause of measles related death (Clements and Hussey, 2004; Moss and Ota, 2007).

Individuals who recover from the virus are immune for the rest of their lives. This means that epidemics are 'self-limiting' and due to the attrition of susceptibles (either through death or immunity), subsequent epidemics can occur (in the absence of migration) only after a new group of susceptibles are born into the population (Giesecke, 2002; Finkenstadt et al., 1998). As such, measles requires a large host population (at least 250,000 people) to become endemic or occur at regular intervals (Bartlett, 1960; Rhodes and Anderson, 1996). Despite a high rate of natural increase, Quebec had a small population compared to France, numbering around 24,564 in 1714. Thus, epidemics would occur at intermittent or more irregular intervals and would not become endemic until much later. Nevertheless, these periodic disturbances probably had a large health, social and economic impact on the population living through that particular time.

The objective of the current study is to analyze the general mortality patterns of the measles epidemic of 1714-15 and to build on the small existing body of literature on epidemics in New France. Particularly, we focus on the origin, spread, duration and severity of the measles epidemic. Additionally, we introduce a set of methods suitable for use with parish data to estimate measles mortality when cause of death information is lacking. In sum, this study is exploratory in nature and serves to identify mortality conditions during the epidemic and will help determine appropriate areas of study for future analyses on the consequences of epidemics at the familial and individual levels.

\section{Data and Methods}

The data used in this study originates from the Registre de population $d u$ Québec ancien, compiled by the Programme de recherche en démographie historique (PRDH) at the Université de Montréal (Légaré, 1988; Charbonneau et al., 1993). The database contains, for individuals that lived in the SaintLawrence Valley in the 17th and 18th centuries, the date and place of birth, death and marriage(s), names of parents and spouse(s) and secondary information on places of residence and of origin. As the development of the database is still in progress, the availability of information varies by time. Currently, births and deaths are matched with individuals and their parents up to the year 1779 and marriages up to 1799 ; also, deaths up to 1850 relating to individuals born before 1750 were also added, to allow for mortality measures. All ancestors of every individual who married before 1800 can be traced back to the founders of the population. 


\section{Data Quality}

The Quebec data are highly reliable and accurate. Records were well organized, duplicates of vital events were kept and relatively few parish records were lost (Charbonneau et al., 2000). However, some information is missing and this could potentially lead to biased estimates. Missing information mostly includes the underregistration of infants dying before baptism, as well as, young children and people who died outside of the parish areas (e.g. voyagers). These losses were evaluated at approximately $10 \%$ of the parish records (Desjardins, 1996). The problem of underregistration could be greater because of the possibility of administrative disorganization during an epidemic. However, Desjardins (1996) examined the data and found that the number of unbaptized infants born during epidemics were no different than the numbers from 'normal' years. Thus, it was concluded that the clergies kept good records at all times.

The above patterns were confirmed in a study by Gagnon and Mazan (2009) using methods involving birth intervals and intervals between birth and baptism (Blum \& Henry, 1988; Charbonneau, 1975; Henry, 1968). For the present study, we use instead "apparent" infant mortality rates, as the data are not corrected for underreporting. As such, our estimates of infant mortality may be lower than those reported using the correction factors (see Nault et al., 1990). However, the correction factors assume that deaths are constant over the year and are more suitable to examine annual rates over a long period of time. In our case, it is crucial to know the precise date of a person's death because measles is seasonal (i.e., death rates are not constant) and if we know the date of death, we can use the seasonal pattern of the virus to estimate whether a child died from measles or not. We assume that the proportional distribution of deaths by cause would be the same for unrecorded individuals.

\section{Regions}

Charbonneau et al. (2000) indicate that records of well-established parishes were globally more complete than those from only recently founded parishes, where the absence of a resident priest, for example, may have caused a greater proportion of underreporting. Including population counts from those parishes would bias mortality estimates downwards because the denominator would be inflated. To alleviate the problem, we only considered 63 well-established parishes (excluding missions). Additionally, we divided the parishes into broad regions to increase the population size and number of events (deaths) so that rates could be estimated (or to reduce the high random variation due to the small number of events). Quebec City and Montreal are presented as their own separate regions or as the administrative urban centres of the colony, while the 
remaining 61 parishes are divided into 4 broad regions or rural areas. Table 1 shows the division of the 63 parishes into six broad regions.

Table 1.

The Designated Urban Towns and Rural Regions, New France 1710-1719

\begin{tabular}{l|l}
\hline \multicolumn{1}{c|}{ Region } & \multicolumn{1}{c}{ Name } \\
\hline Rural West & $\begin{array}{l}\text { North of Montreal, South of Montreal \& } \\
\text { Remainder of Montreal Island }\end{array}$ \\
Urban West & Monteal \\
Central & Troisières \& Portneuf \& Lotbinière \\
Urban East & Quebec City \\
Greater Quebec Area (GQA) & Parishes surrounding Quebec City \\
Rural East & $\begin{array}{l}\text { Orleans Island, Beaupre/Charlevoix, } \\
\text { Bas-St. Laurent/Beauce }\end{array}$ \\
\hline
\end{tabular}

\section{Study Population}

The study population consists of inhabitants residing in the 63 established parishes (6 regions) between 1710 and 1719. We selected Canadian born individuals less than 15 years of age with a registered date of birth and a known parish of death within the colony. We only focus on infants and children up to age 15 because $79 \%$ of the recorded deaths occurred in those age groups during the epidemic. Further selection criteria were implemented in order to derive an estimate of the population size for each of the regions. Internal migration was quite common in the colony and if the transient population was not taken into consideration, estimates could be significantly biased.

A simple method to lessen the potential bias introduced by internal migration is to estimate the region of residence for each individual by using information about other family members. We used the following criteria: 1) If all family members were born and died in the same parish, this was used as the place of residence for each year; 2) When the parish of birth and death were 
different for some members and there was a birth or death in the family during the year of interest, we used the recorded parish of the event as the place of residence for the entire family and; 3) Otherwise, the parish with the most recent birth or death prior to the year of interest was designated as the current residence of that particular family. Table 2 shows the population estimates and vital events of the six regions between 1710 and 1719 .

\section{Estimation of Mortality from Measles}

Since parish priests did not record the cause of death, we cannot get a direct estimate of measles mortality rates. Thus, we indirectly estimated the expected or normal quarterly death rate, ${ }_{n} \hat{m}_{x}$ to derive risk ratios and a set measles death rates or ${ }_{n} m_{x}^{\text {measles }}$. The choice of a functional form to identify large deviations from the normal rate is not without problems. For instance, a single functional form fit with ordinary least squares is sensitive to outliers (or the peaks and troughs of a time series) and these tend to pull the fitted line in their direction (Palloni, 1990). This influence may distort any 'real' difference between normal and non-normal conditions.

When a single functional form cannot produce a satisfactory fit to the data, one alternative would be to fit a spline over sub ranges of the data (London, 1985). A cubic spline is a piecewise polynomial that is twice continuously differentiable (Prenter, 1975). The data range is divided into $n$ piecewise curves, which are joined together smoothly by $n-1$ internal knots $\left(k_{i}\right)$. In the present study, we fit a series a smoothing splines through all data points between the $1^{\text {st }}$ quarter of 1710 and the $4^{\text {th }}$ quarter of 1719 to estimate the expected death rate or ${ }_{n} \hat{m}_{x}$. We found that a good approximation of normal mortality was obtained by dividing the data range $(y, z)$ into three segments, joined together by two internal knots, at $x=k_{1}$ and $x=k_{2}$. Parameters of the cubic splines were estimated by weighted least squares, where the sum of squares minimizing equation is (London, 1985: 103):

$S S=\sum_{a}^{h_{1}}{ }_{n} w_{x}\left[{ }_{n} m_{x}-{ }_{x} \hat{m}_{x(0)}\right]^{2}+\sum_{h_{1+1}}^{h_{2}}{ }_{n} w_{x}\left[{ }_{n} m_{x}-{ }_{n} \hat{m}_{x(1)}\right]^{2}+\sum_{h_{2+1}}^{b}{ }_{n} w_{x}\left[{ }_{n} m_{x}-{ }_{n} \hat{m}_{x(2)}\right]^{2}$ 


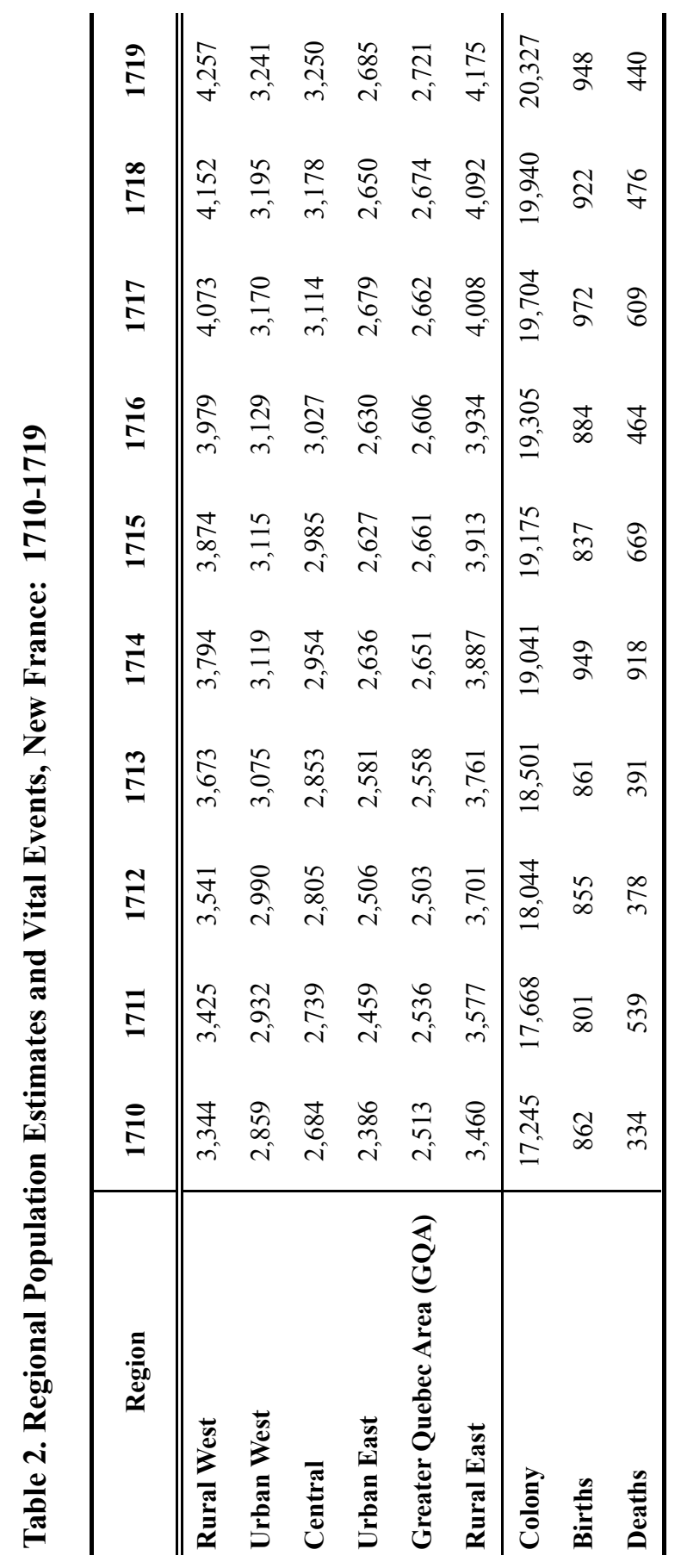


where $h_{1}$ is the closest value of $x$ less than or equal to $k_{l}, h_{2}$ is defined the same with respect to $k_{2}$, and are the weights (for a more formal treatment of the subject see London, 1985: 102-107; Benjamin \& Pollard, 1980: 345-355). The weights or ${ }_{n} w_{x}$ are the reciprocal of the variance. For infants, VAR $\left({ }_{n} m_{x}\right)$ was assumed to be binomially distributed (see Chiang, 1984: 84), while for 1 to 4 and 5 to 14 year olds, we used the Poisson approximation to the binomial distribution $\left(1 /\left({ }_{n} m_{x}^{2} /{ }_{n} D_{x}\right)\right)$. The Poisson approximation is computationally easier and when the number of events $\left({ }_{n} D_{x}\right)$ is small and the population at risk is large $\left({ }_{n} P_{x}>100\right)$, both methods produce similar variance estimates. The following prediction equations for each of the 3 segments can be substituted into formula [1]:

$$
\left.\begin{array}{l}
{ }_{n} \hat{m}_{x(0)}=a+b_{x}+c_{x}^{2}+d_{x}^{3} ; \text { for } y \leq x \leq k_{1} \\
{ }_{n} \hat{m}_{x(1)}=a+b_{x}+c_{x}^{2}+d_{x}^{3}+e\left(x-k_{1}\right)^{3} ; \text { for } k_{1} \leq x \leq k_{2} \\
{ }_{n} \hat{m}_{x(2)}=a+b_{x}+c_{x}^{2}+d_{x}^{3}+e\left(x-k_{1}\right)^{3}+f\left(x-k_{2}\right)^{3} ; \text { for } k_{2} \leq x \leq z
\end{array}\right]
$$

where $y=1\left(1^{\text {st }}\right.$ quarter of 1710$), z=40\left(4^{\text {th }}\right.$ quarter of 1719$), k_{1}=15.5$ and $k_{2}=$ 30.5. The location of the knots were determined by a visual examination of line graphs for each of the age groups and regions (e.g. see figures 1 and 2). It was found manually that the knots could be placed in the same location for each of the groups. Predicted quarterly rates $\left({ }_{n} \hat{m}_{x}\right)$ serve as an estimate of the normal quarterly death rate for ages $x$ to $x+n$. These are the expected morality conditions in the absence of period disturbances such as, epidemics.

To examine the origin, spread and duration of the epidemic, we estimated ${ }_{n} \hat{m}_{x}$ for the colony by age (i.e., neonatal ( $<28$ days), post neonatal ( 28 to 365 days), infants ( $<365$ days), 1 to 4 year olds and 5 to 14 year olds). The age-specific quarterly death rates were annualized to adjust for differences in the number of days in each quarter and to facilitate comparability between the quarters and regions. These rates were then divided by the expected annual rate of the colony to produce age-specific risk ratios for each of the regions $\left({ }_{n} R R_{x}={ }_{n} m_{x} / \hat{m}_{n}\right)^{1}$.

Figure 1 shows an example of smoothing splines fit through a series of neonatal and post-neonatal mortality rates (or $m_{<28}, m_{28-365}$ ) to estimate the 
Figure 1

Cubic Spline Function to Estimate the Expected Death Rate of the Colony Neonatal and Post-neonatal Mortality: 1710-1719

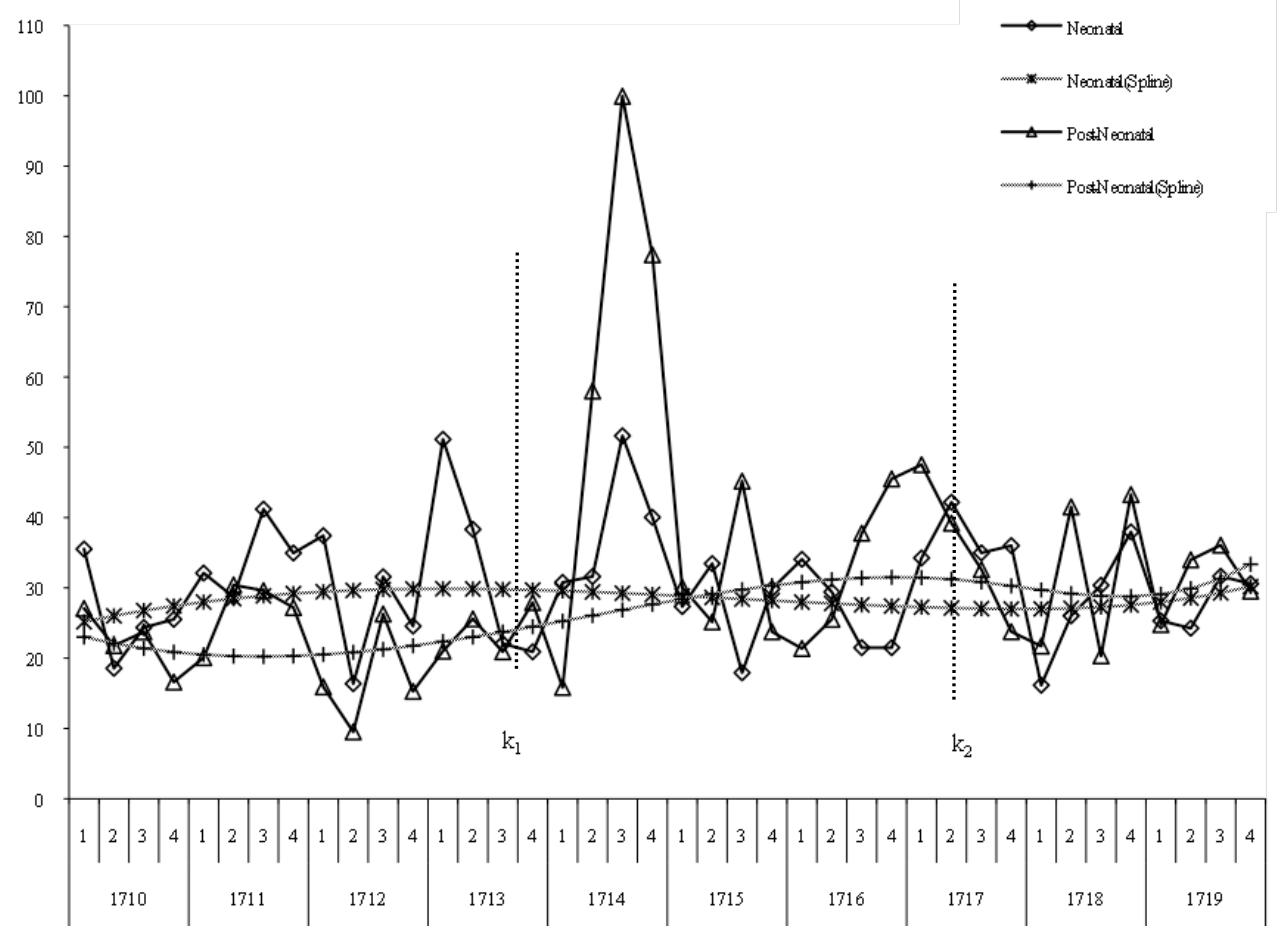


expected rates, $\hat{m}_{<28}$ and $\hat{m}_{28-365}$ for the colony. The trends in the graph may reflect a general worsening of the environment in the colony, as post neonatal mortality (exogenous) became higher than neonatal mortality (endogenous; see Lalou, 1990).

To estimate the measles death rates we have to make another general assumption. If we consider that the cause of death categories are mutually exclusive and exhaustive, then the measles and the expected death rates (i.e. ${ }_{n} m_{x}^{\text {measles }}$ and ${ }_{n} \hat{m}_{x}$ ) are additive and their sum equals the overall observed death rate $\left({ }_{n} m_{x}\right)$ or ${ }_{n} m_{x}={ }_{n} \hat{m}_{x}+{ }_{n} m_{x}^{\text {measles }}$. Clearly, the assumption can be unrealistic. There could be overlap from other causes of death that we do not know about. For instance, measles can precede or accompany other viruses such as influenza. In that sense, a child may recover from a bout with measles, but die from influenza following the measles epidemic. The measles virus can impair the immune system for up to a year after the initial epidemic, making the individual susceptible to other infections (Clements and Hussey, 2004).

The above scenario could mean that cause of death boundaries are overlapping and the difference between the true and estimated parameters are distorted. In the absence of cause of death records, there is never an exact way to know how someone died. However, we still can derive an acceptable estimation of measles deaths by fitting a series of smoothing splines through the data points. For simplicity, the assumption allows ${ }_{n} m_{x}^{\text {measles }}$ to equal the residual difference between the observed and predicted rates or ${ }_{n} m_{x}^{\text {measles }}={ }_{n} m_{x}-{ }_{n} \hat{m}_{x}$. Figure 2 shows the general procedure of obtaining an estimate of ${ }_{1} \hat{m}_{0}$ and ${ }_{1} m_{0}^{\text {measles }}$ in Montreal and Quebec City from the observed data. The trends of the splines show a clear worsening of general morality conditions in Montreal, as compared to Quebec City.

\section{Results}

\section{Origin, Spread and Duration}

The origin, spread and duration of the measles epidemic can be found through an examination of the risk ratios of infant and childhood mortality. Figures 3 a) through e) show the observed quarterly mortality rates of the six regions. Table 3 shows the annualized quarterly age-specific risk ratios by region and quarter. The range of shades in the table portrays the hot and cold spots during the 
Figure 2

Cubic Spline Function to Estimate the Expected and Measles Death Rates

Among Infants for Montreal and Quebec City: 1710-1719

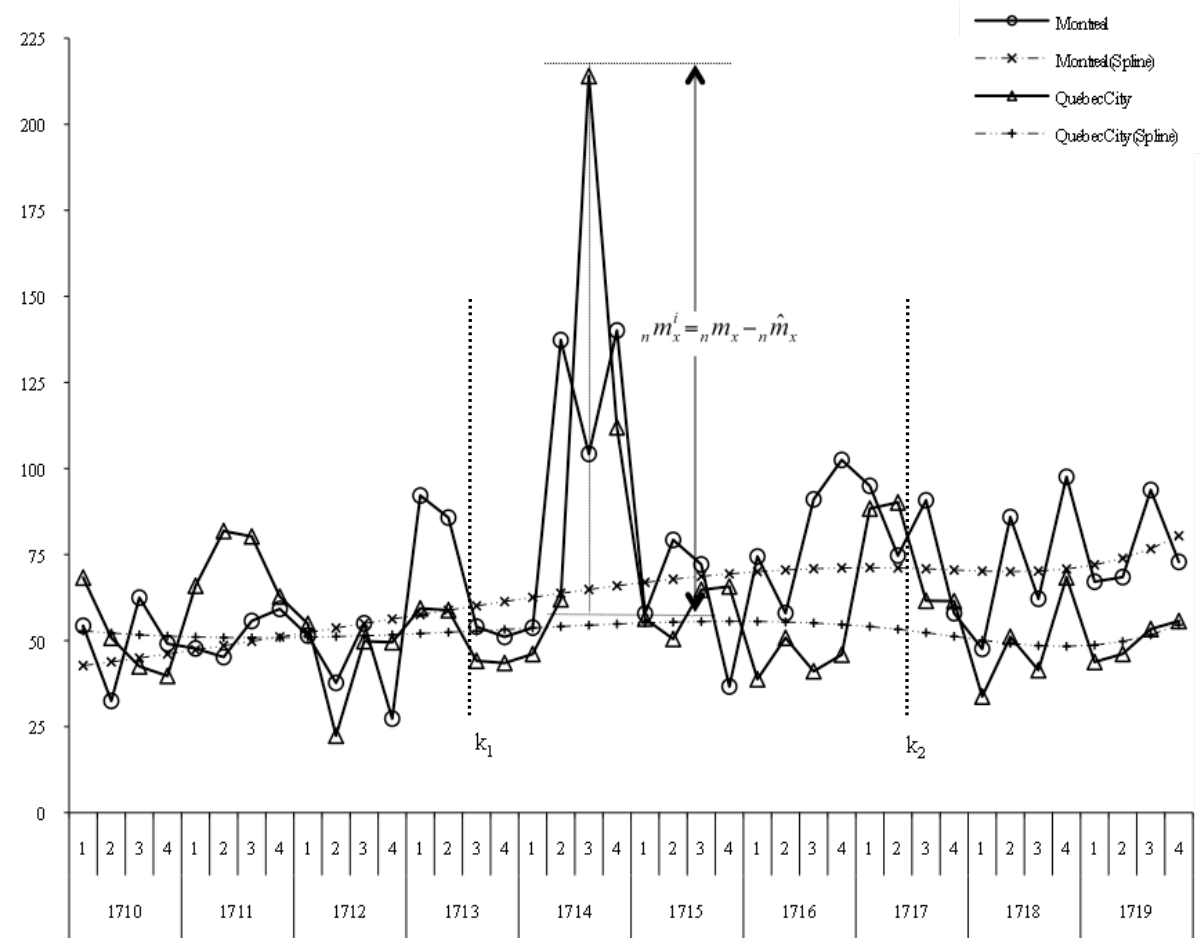


epidemic. For example, no shade indicates lower to slightly higher than expected mortality, while darker shades indicate a much higher than expected rate. The graphs and risk table should be used in conjunction with one another to give a clear picture of the events in 1714 and 1715 .

As mentioned above, we do not have detailed cause of death records, which would help us identify the event as a measles epidemic. However, historical accounts in colonial America report a 'serious' measles epidemic between 1713 and 1715 (see Introduction). The origin of the virus is unknown, but many fatalities were reported in Boston, Massachusetts. The epidemic began in the late summer of 1713 and had run its course by the end of January 1714. By February of that year, the virus had spread to New York, New Jersey, Connecticut and Pennsylvania (Duffy, 1953).

There is no indication that the epidemic had spread into New France at that time. Mortality levels in the $1^{\text {st }}$ quarter of 1714 were at or below normal throughout colony. However, by the spring of 1714, a sudden increase in mortality appeared in the Western parishes. As seen in Figures 3 a) through e) and Table 3, all age groups in Montreal had higher than normal death rates. For instance, post-neonatal risk ratios reached 3.27 times the normal rate in Montreal. The patterns observed in the risk table give a good indication that the virus originated in the Western area of the colony. Another factor is that Aboriginals usually traveled from the American territory to the French colony via a canoe route consisting of the Hudson River, Lake Champlain and the Richelieu River. As such, we believe that the Canadian origin of the epidemic was somewhere around Montreal and the surrounding Rural parishes during the $2^{\text {nd }}$ quarter of 1714 (around April). It then spread eastward and reached the Central and Eastern parishes near the end of the $3^{\text {rd }}$ quarter (around September).

By the late $3^{\text {rd }}$ quarter of 1714 , the risk of death was elevated in all areas, particularly in the Eastern parishes. Notice that neonatal risk is not as pronounced as in the other age groups. Neonates may have incurred some advantage, as maternally acquired antibodies tend to provide protection against measles during the first months of life (Moss and Ota, 2007). Interestingly, postneonatal and early childhood death ratios declined in Montreal between the $2^{\text {nd }}$ and $3^{\text {rd }}$ quarters, but increased again by the $4^{\text {th }}$ quarter. These distinct crown shaped (or bimodal) mortality peaks are evident in figures $3 \mathrm{~b}$ ) and $3 \mathrm{~d}$ ). During that time, mortality levels peaked in the Central parishes, Quebec City and the Rural East. For 1 to 4 year olds, mortality peaked during the fourth quarter of 1714 in all areas, with Quebec City having the highest risk ratio at 12.85 times the normal rate. Mortality began approaching expected levels by the first quarter of 1715, except in Quebec City, where the risk remained 3.46 times higher than normal. 


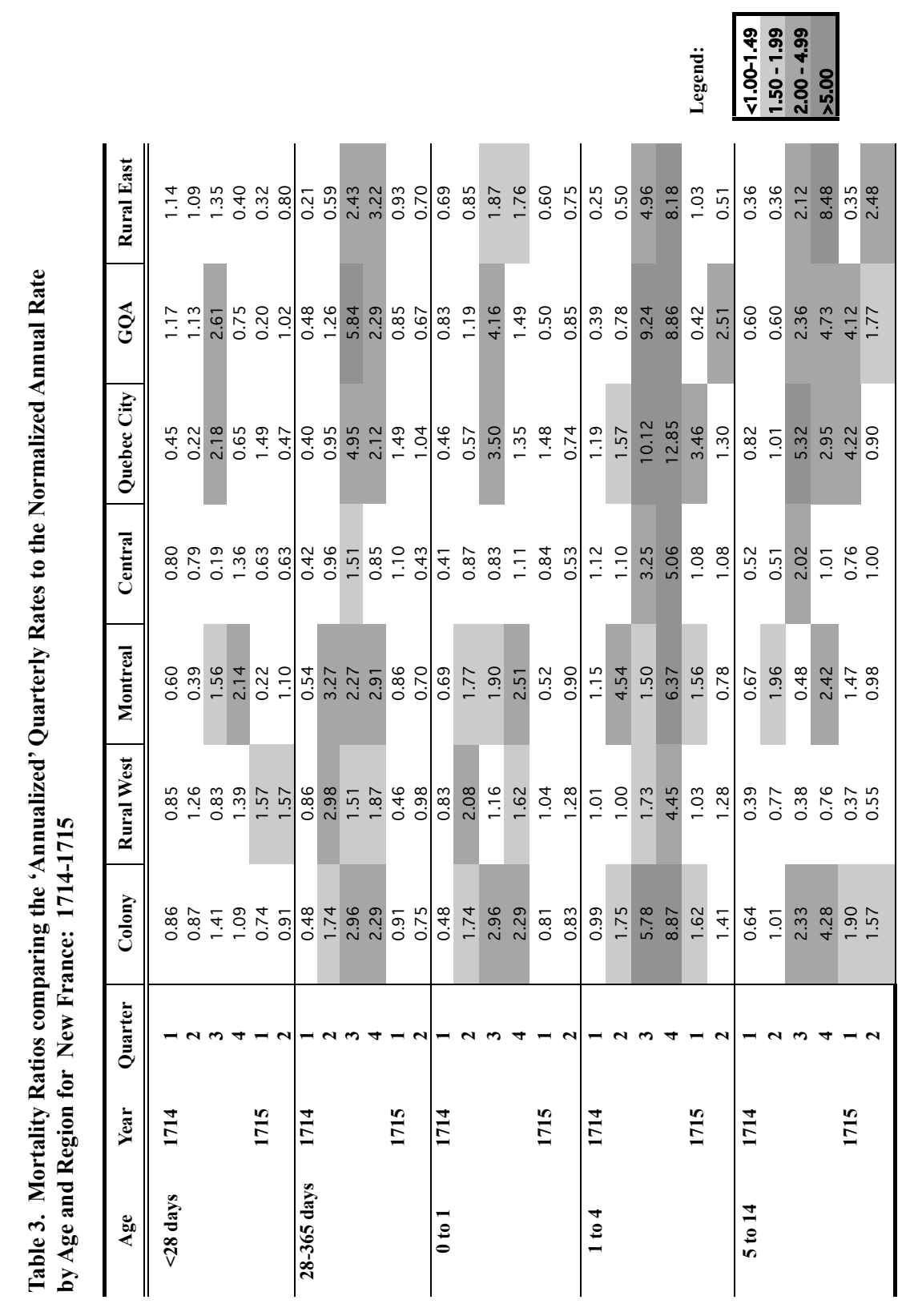

CSP 2009, 36.3-4: 295-323 
Figure 3. Quarterly Mortality Rates for

a) Neonatal, b) Post-Neonatal, c) Infant, d) 1 to 4 year olds, and e) 5-14 year olds by Region and Age Group for New France: 1713-1715

a) Neonatal

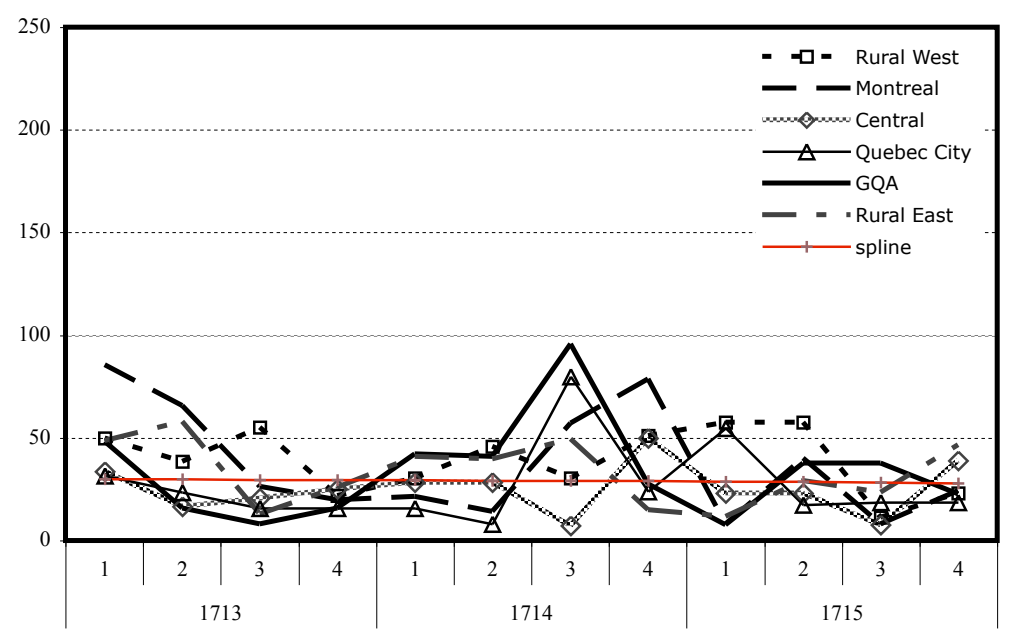

b) Post-Neonatal

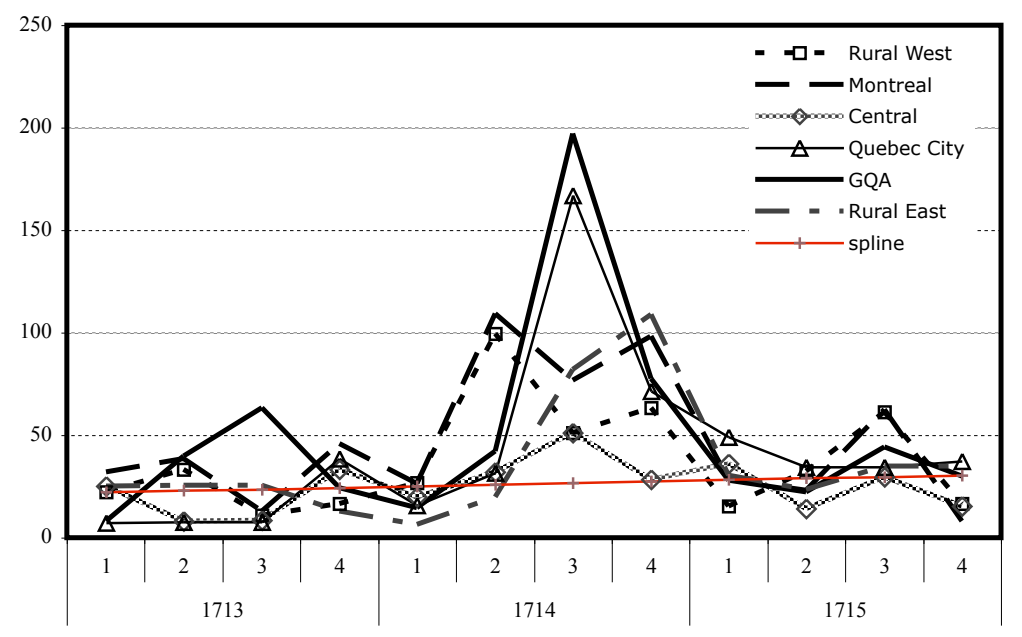


Figure 3. (Continued)

c) Infant

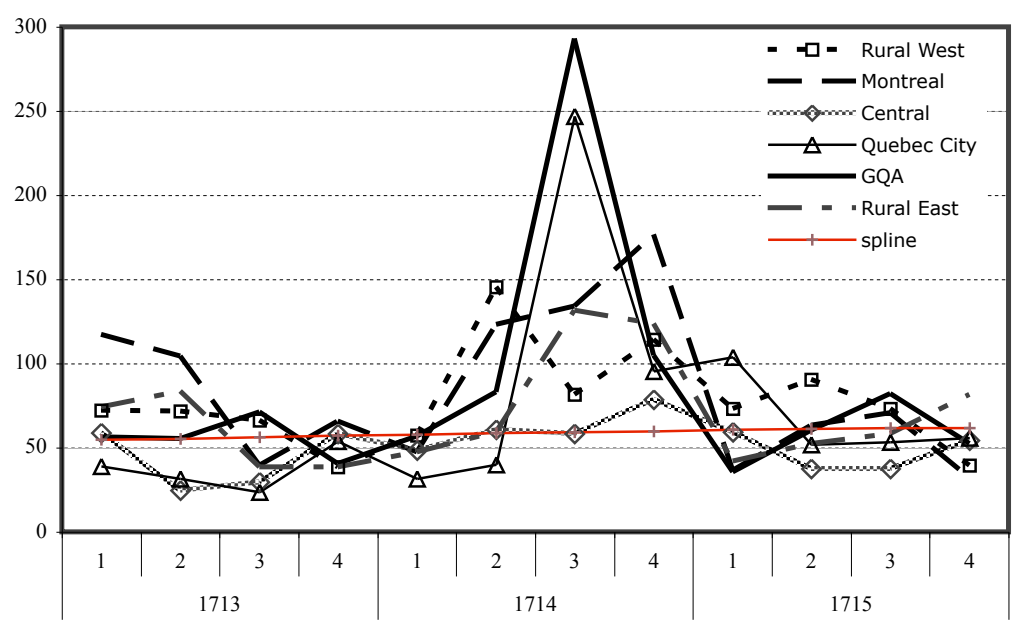

d) 1 to 4 years

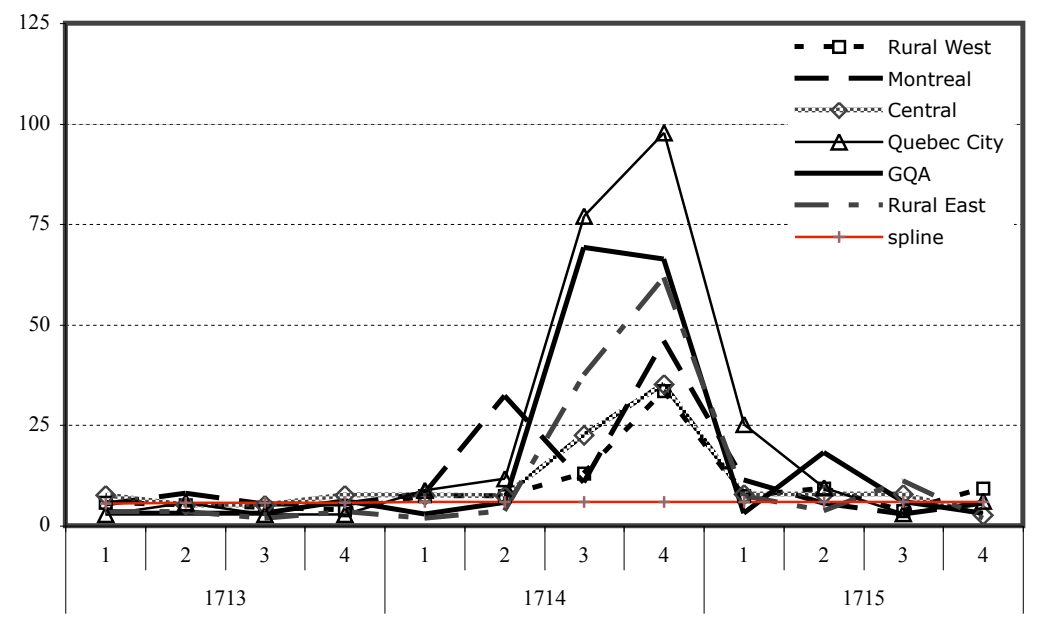


Figure 3. (Continued)

\section{e) 5 to 14 years}

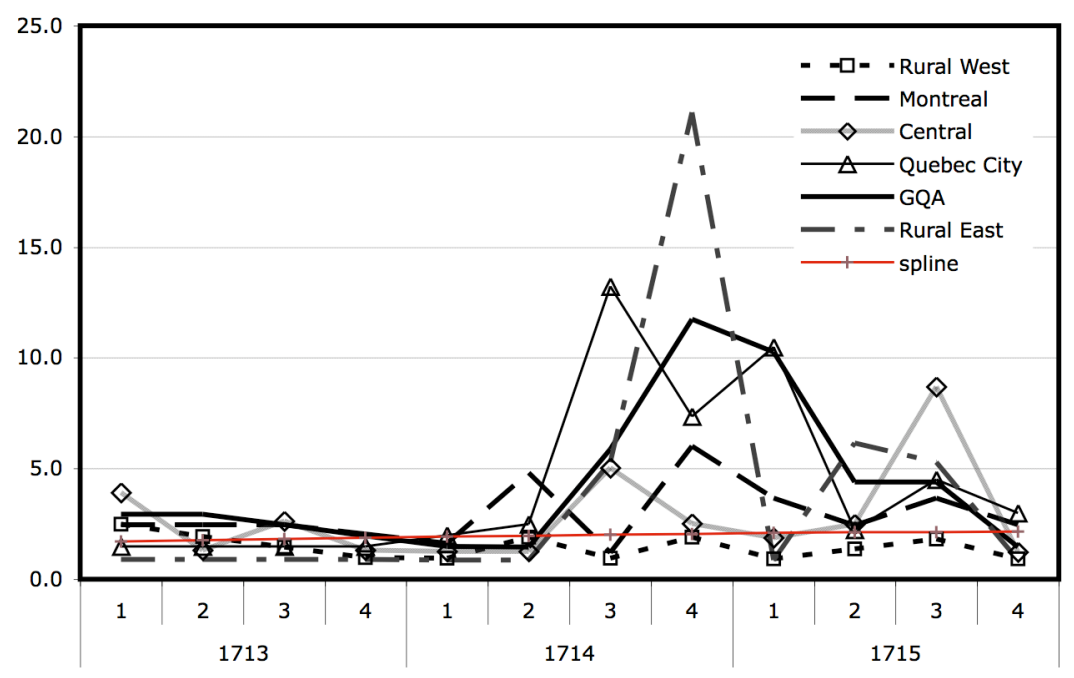

In most regions, mortality rates among 5 to 14 year olds (later childhood) were also elevated during the epidemic. Risk ratios ranged from a low of .76 in the Rural West to a high of 8.48 times the normal rate in the Rural East. The elevated risk of death in the East continued well into 1715 and began to return to normal levels by the $2^{\text {nd }}$ quarter of that year. Curiously, the rates in the Rural West remained well below the expected rate for the entire duration of the epidemic. This pattern suggests that residents had a better chance of recovery or were previously exposed to measles and had acquired immunity. At this point, however, we are not aware of any other serious measles epidemics taking place before this one. These patterns may be more of an indication of a higher chance of recovery from the virus (possibly, better nutrition). Additionally, infants in the Central region had a much lower risk ratio than infants in the other regions. This trend could be the result of greater isolation and lower contact density. Colonists usually travelled from Montreal to Quebec City or vise versa without stopping in Trois-Rivières.

Notice that post-neonatal and 5 to 14 year old mortality rates were also elevated during the $3^{\text {rd }}$ quarter of 1715 (refer to Figures $3 \mathrm{~b}$ and $3 \mathrm{c}$ ). We believe this surge may be the result of another epidemic or delayed measles 
complications. This may also be the case with elevated ratios in the $2^{\text {nd }}$ quarter of 1715. After a measles epidemic, recovering individuals are immunocompromised and are more susceptible to other infections. It is believed that morbidity and mortality are increased for up to a year after the initial epidemic (Clements and Hussey, 2004). In our case, the excess deaths in the $3^{\text {rd }}$ quarter occurred in July and tend not to follow the typical seasonal pattern of measles in North America (i.e. autumn to later winter/spring). In addition, a smallpox epidemic was reported in New York and other parts of the American colonies during the summer of 1715 (Duffy, 1953). This epidemic may have also reached New France, as well. As such, we do not consider the increased rates as a direct result of the 1714 measles epidemic. Taking these factors into consideration, we believe that the epidemic may have lasted somewhere around 15 months or between the $2^{\text {nd }}$ quarter of 1714 and the $2^{\text {nd }}$ quarter of 1715 .

\section{Estimated Deaths from Measles}

Now that we have an idea on the origin, spread and duration of the measles epidemic, we turn to its severity. This is accomplished by estimating the measles death rates by age, sex and region (refer to Appendix Tables 1a through 1d). Annual rates are shown, but estimates for 1 to 4 and 5 to 14 year olds do not follow the normal calendar year. These estimates coincide with the duration of the epidemic. For 1 to 4 year olds, we examine deaths between the $2^{\text {nd }}$ quarter of 1714 and the $1^{\text {st }}$ quarter of 1715 , while for 5 to 14 year olds we examine deaths occurring between the $3^{\text {rd }}$ quarter of 1714 and the $2^{\text {nd }}$ quarter of 1715 . Although the epidemic may have had a longer duration, we only show the 12 months when most of the regions were infected.

\section{Normal Mortality Conditions}

Before we examine the severity of the epidemic, we first give a brief description of the expected level of mortality under normal conditions (based on rates estimated with the splines). For infants, the probability of death under normal conditions was estimated at 230 deaths per thousand live births, with males at a slightly higher risk of death. As we mentioned above, our estimates of infant mortality will be lower than those of others because we did not correct for underreporting (see Data Quality section). For instance, other estimates of infant mortality range from 240 to 246 deaths per thousand live births roughly during this time period (Henripin, 1954; Charbonneau, 1975; Lalou, 1990; Gagnon and Mazan, 2009). Mortality also varied by region with the West having the highest rate (261.5 per thousand) followed by the East (219.9 per thousand) and Central Regions (177.7 per thousand). Montreal had the highest level of infant mortality 
in the colony, where $28.4 \%$ of infants would die before their first birthday. Generally, early childhood mortality ( 1 to 4 year olds) was slightly higher among females throughout the entire decade. For older children (5 to 14 year olds), the expected death rate was around 7 per thousand for both males and females. Mortality in the Central region appeared to be the highest (9.3 per thousand), while rates in the West and East were about the same ${ }^{2}$.

\section{Epidemic Conditions}

Survival prospects worsened for children under the age of 15 when the measles epidemic appeared in the colony during the early spring of 1714 (refer to Tables 1 a) through d) in the Appendix). Based on our spline functions described in the methods section, we estimated an overall measles death rate of 52.8 per thousand for children under age 15, which accounted for approximately $59.6 \%$ of all deaths. We also estimated that $43.2 \%$ of all deaths among infants, $78.4 \%$ for 1 to 4 year olds and $64.8 \%$ for 5 to 14 year olds could have been from the measles virus. Children in the East had the highest measles death rate, as they were 2.1 and 3.4 times more likely than children in the West and Central regions to die from measles (i.e. 75.7 vs. 35.4 and 22.4 per thousand).

Overall, infant measles death rates in the East and West were quite similar: $21.2 \%$ of infants died from measles in the East, while $17.2 \%$ died in the West. Only $4.9 \%$ infants died from measles in the Central region. Among young children, however, measles death rates varied considerably by region. The measles death rate for this age group was estimated to be highest in Quebec City (181.8 per thousand), followed by the Rural East (101.5), Montreal (76.8), Central (48.4) and Rural West (39.4). On average, young children in the East were 2.3 times as likely as those in the West and Central regions to have died from the virus.

In Quebec City, the epidemic must have been quite severe among young children, as infants only had a $6.9 \%$ higher risk of measles death than 1 to 4 year olds (i.e. 194.3 vs. 181.8 per thousand). In comparison, infants in Montreal were 2.6 times more likely to die from measles than young children. Similarly, older children in the West had had a much lower risk of death than children in the East and Central Regions. In the Rural West, there is no clear evidence that any child aged 5 to 14 years died from measles. On the other hand, high measles death rates were evident in the Eastern parishes. Children in the East were 2.2 and 5.6 times more likely to die from measles than those residing in the Central region and Montreal, respectively.

Generally, females under 15 years of age were slightly more likely than males to die from measles (55.1 vs. 49.4 per thousand). Lower survival among females is consistent with a study of measles mortality in 78 countries between 1950 and 1989 (Garenne, 1994). Sex differences become even clearer when ages 
are broken down into their standard groupings. Female infants had $17 \%$ higher mortality from measles than males, while for 1 to 4 year old males had a slightly higher risk of death. The latter pattern is not unusual because some studies have found no clear sex difference (Moss and Ota, 2007). For 5 to 14 year olds, we estimated that females were almost twice as likely as males to have died from measles (17.8 vs. 9.1 per thousand). Garenne (1994) also found a similar pattern in this age group (though not as large of a difference).

The factors that contribute to the differences are largely unexplained. It is not clear whether the sex difference is biologically or socially based (Clements and Hussey, 2004). More than likely, it is a combination of social and biological differences. Although females generally had a higher risk of death from measles, the epidemic had severe consequences on male children as well.

\section{Discussion and Conclusion}

A severe measles epidemic entered the Western part of New France during the $2^{\text {nd }}$ quarter of 1714 (in late March). By the $3^{\text {rd }}$ quarter (around September), the epidemic had spread to most parts of the colony and had run its course by the $2^{\text {nd }}$ quarter of 1715. Although we do not have detailed cause of death data for that time, we were able to estimate measles death rates by fitting a series of smoothing splines through the data by age, sex and region. We found that the epidemic was quite severe among all age groups, but the severity declined with age and varied by region. However, risks ratios comparing epidemic with normal mortality conditions were generally higher for children than for infants. Children in the East had the highest risk of death in the colony, while females were more likely than males to have died from measles. This sex differential continues to be observed in modern populations (Garenne, 1994).

A further issue that needs to be addressed are the possible reasons for the high number of measles fatalities in the colony. Measles epidemics can be of mild to severe forms, but this epidemic proved to be often fatal for children less than 15 years of age. Practitioners in 18th century England reported that most healthy children 'rarely' died from measles (Duncan et al., 1997). Rather, death was more common in infants of 'weak constitution', particularly among the working class in the large cities. If healthy children have a higher chance of recovery from measles infection, then there must have been an event in the colony that would have acted as a 'trigger' for the mortality crisis. According to Palloni (1990), there is usually a 'triggering event' preceding any crisis.

In the case of New France, the triggering event could have been poor climatic conditions. Duncan et al. (1997) found that, low spring and autumn temperatures were associated with measles epidemics and mortality in $17^{\text {th }}$ and $18^{\text {th }}$ century England. Further, Canada has always been well known for its frequent cold snaps and, generally, as a nation with a 'cold climate'. These 
trends coincide with the seasonal patterns of the measles virus. In the Northern Hemisphere, measles epidemics usually peak during the spring, autumn and early winter months (when contact density increases) (Cliff et al., 1998).

In turn, a poor climate could have led to poor harvests, food shortages containing essential vitamins and even malnutrition. In fact, "poor to disastrous harvests" were reported in New France between 1714 and 1717 (Crowley, 1991). There was no indication of the exact regions affected or whether the entire colony experienced poor harvests. Judging by the severity of the epidemic, the children in the East would be in the disadvantaged situation. The farming season in the Eastern (northern) regions are shorter than in the West. Also, the soils were very fertile in the plains around Montreal and the land was easier to cultivate than in the Eastern region of Charlevoix. Poor harvests may have led to nutritional deficiencies and left the colonists in a vulnerable state.

Malnutrition is regarded as a major predictor of measles mortality. In $17^{\text {th }}$ and $18^{\text {th }}$ century England, for instance, measles mortality was found to be positively associated with wheat prices (a proxy for malnutrition) (Duncan et al., 1997). It is believed that the influence of malnutrition is mediated through immune suppression (Clements and Hussey, 2004). In particular, vitamin A deficiency and protein energy malnutrition are the common nutritional risk factors associated with an increased risk of death. Vitamin A is essential because it replenishes epithelial cells (the first line of defense) and helps regulate the immune system, which prevents or fights off infections by producing white blood cells to destroy harmful bacteria or viruses. An infected person with a vitamin A deficiency tends to have an increased risk of developing complications associated with measles immune suppression such as, severe diarrhoea and pneumonia (Moss and Ota, 2007). As such, the WHO recommends giving high doses of vitamin A supplements to infected children in areas where vitamin A deficiency is widespread or the measles case fatality rate is $1 \%$. Arguably then, an improved diet and Vitamin A supplementation during an epidemic leads to a 'marked fall' in measles mortality (Barclay et al., 1987; Berman, 1991; Clements and Hussy, 2004).

Another possibility for the high death rates is overcrowding in households. Several community studies on Africa, Asia and Europe found that mortality was higher in families with several cases and among secondary cases (i.e. children infected at home). In these studies, the 'effect of malnutrition was less important than overcrowding and intensive exposure to the virus' (Garenne and Aaby, 1989; Aaby, 1984; 1988). Generally, it is suggested that close contact with other family members serves to increase the generational intensity of the virus. The increased mortality risk associated with close family contact is explained as a 'dose-response effect': the closer the contact between family members, the higher the dose of infective particles transmitted and the higher the mortality of the other family members (Garenne and Aaby, 1989). As such, 
this implies that the effect of crowding and clustering on the risk of death may be mediated through intensive exposure to the virus.

In other community studies, the age at infection and family size have also been found to be important risk factor of measles mortality (Reves, 1985; Pison et al., 1992; Burstrom et al., 1999). Pison et al. (1992) found that a larger age difference between sibling pairs resulted in a higher odds of death from measles. In the case of Quebec, older children were probably more likely to be infected outside of the home (index child) and then infect the younger children in the household (secondary cases). Older children would have a better chance of fighting off the infection because of a fully developed immune system. Younger children, on the other hand, would be at a dual disadvantage because of an underdeveloped immune system and further suppression due to widespread malnutrition. In turn, younger children who contract the virus, given the ageassociated differences in risk and the intensity hypothesis, would have a greater likelihood of dying (Reves, 1985; Pison et al., 1992; Burstrom et al., 1999). These issues are addressed in a forthcoming study.

As New France was considered a 'natural fertility' population, a typical family would usually have a large number of young children in the household. If crowding or sibling transmission were the more important determinants, then we would expect mortality rates to be similar in each region, as family size was equally large in all parts of the colony. This is clearly not the case, as overall measles mortality was estimated to be higher in the East. Thus, we suspect that the severity of the epidemic was largely a result of widespread malnutrition or vitamin A deficiency in the East. These circumstances probably made the inhabitants highly vulnerable and contributed to the higher number measles deaths in that particular region.

\section{End Notes}

1. One should exercise caution when interpreting the ratios, as some of the observed rates are based on a small number of events. For instance, a small increase in the number of deaths can produce larger than normal level of risk in the population. As such, large fluctuations may be a combination of random variation and excess mortality from the epidemic. However, the risk table should allow one to gauge an approximate level of risk relative to 'normal' mortality conditions in the colony.

2. Estimates of mortality at this age in the Central region are based on a smaller number of events. As such, these estimates are subject to a higher degree of random variation than the other regions. 


\section{References}

Aaby P. 1988. "Malnutrition and overcrowding/intensive exposure in severe measles infection: Review of community studies". Review of Infectious Diseases 10: 478-491.

Aaby P., Bukh J., Lisse I. M., Smits A. J. 1984. "Overcrowding and intensive exposure as determinants of measles mortality". American Journal of Epidemiology 120: 49-63.

Barclay A. J. G., Foster A., Sommer A. 1987. "Vitamin A supplements and mortality related to measles". British Medical Journal 294: 294-296.

Bartlett M. S. 1960. "The critical community size for measles in the United States". Royal Statistical Society, Series A 123: 37-44.

Benjamin B., Pollard J. H. 1980. The Analysis of Mortality and Other Actuarial Statistics. London: Heinemann.

Berman S. 1991. "Epidemiology of acute respiratory infections of children in developing countries". Review of Infectious Diseases 13: S454-S462.

Blum, A., Henry, L. 1988. Techniques d'analyse en démographie historique. Paris: INED.

Burstrom B., Diederichsen F., Smedman L. 1999. Child mortality in Stockholm during 1885-1910: The impact of household size and number of children in the family on the risk of death from measles. American Journal of Epidemiology 149: 1134-1141.

Charbonneau H., Desjardins B., Guillemette A., Lardry Y., Légaré J., Nault F. 1993. The First French Canadians: Pioneers in the St. Lawrence Valley. Newark: University of Delaware Press.

Charbonneau H., Desjardins B., Légaré J., Denis H. 2000. “The population of the St. Lawrence Valley, 1608-1760" in A population History of North America. Haines M. R., Steckel R .H. (ed.). Cambridge, Cambridge University Press, pp. 99-142.

Charbonneau H. 1975. Vie et Mort de nos Ancêtres Montréal. Montréal: Les Presses de l'Université de Montréal.

Chiang C. L. 1984. The Life Table and its applications. Florida: Robert E. Krieger Publishing.

Clements C. J., Hussey G. D. 2004. "Measles" in The Global Epidemiology of Infectious Diseases. Murray C. J. L., Lopez A. D., Mathers C.D. (ed.). Geneva: WHO. 
Dechene L., Robert J-C. 1993. "Le cholera de 1832 dans le Bas-Canada: mesure des inegalites devant la mort" in The Great Mortalities: Methodological Studies of Demographic Crises in the Past. Charbonneau H., Larose A. (ed.). Belgium: Oridona Editions (IUSSP), pp. 229-256.

Desjardins B. 1996. "Demographic aspects of the 1702-1703 smallpox epidemic in the St-Lawrence valley". Canadian Studies in Population 23(1): 49-67.

Duffy J. 1953. Epidemics in Colonial America. Baton Rouge: Louisiana State University Press.

Duncan C. J., Duncan S. R., Scott S. 1997. "The dynamics of measles epidemics". Theoretical Population Biology, 52: 155-163.

Finkenstadt B., Keeling M., Grenfell B. 1997. "Patterns of density dependence in measles dynamics". Proceedings of the Royal Society B 265: 753-762.

Gagnon A., Mazan R. 2009. Does exposure to infectious diseases in infancy affect old age mortality? Evidence from a pre-industrial population. Social Science and Medicine 68: 1609-1616.

Garenne M. 1994. "Sex differences in measles mortality: A world review". International Journal of Epidemiology 23: 632-642.

Garenne M., Aaby P. 1989. "Patterns of exposure and measles mortality in Senegal". Journal of Infectious Diseases 16: 1088-1094.

Giesecke J. 2002. Modern Infectious Disease Epidemiology. London: Arnold.

Henripin J. 1954. La Population Canadienne au Début du XVIIIe Siècle: Nuptialité, Fécondité, Mortalité Infantile. Paris: Presses universitaires de France.

Henry L. 1968. "The verification of data in historical demography”. Population Studies 22: 61-81.

Lalou, R. 1990. Des Enfants pour le Paradis. La Mortalité des Nouveau-nés en Nouvelle-France. Thèse présentée à la Faculté des études supérieures en vue de l'obtention du grade de philosophiae doctor (démographie). Université de Montréal.

Légaré J. 1988. "A population register for Canada under the French regime: Context, scope, content, and applications". Canadian Studies in Population 15: 1-16.

London D. 1985. Graduation:The Revision of Estimates. Winsted and Abington, Connecticut: ACTEX Publications. 
Moore C. 1997. "Colonization and conflict: New France and its rivals 1600-1760" in The Illustrated History of Canada. Brown C. (ed.). Toronto: Key Porter Books Limited, pp. 105-188.

Moss W. J., Ota M. O. 2007. "Measles" in Infectious Disease Epidemiology: Theory and Practice, Nelson K. E., Williams C. M. (ed.). Boston: Jones and Bartlett Publishers, pp. 601-621.

Murray G. D., Cliff A. D. 1977. "A stochastic model for measles epidemics in a multi-region setting". Transactions of the Institute of British Geographers 2: $158-174$.

Nault F., Desjardin B., Légaré J. 1990. "Effects of reproductive behaviour of French Canadians during the seventeenth and eighteenth centuries". Population Studies 44: 273-285.

Palloni A. 1990. "Assessing the levels and impact of mortality in crisis situations" in Measurement and Analysis of Mortality: New Approaches. Vallin J., D'Souza S., Palloni A. (ed.). Oxford: Clarendon Press, pp. 195-228.

Pison G., Aaby p., Knudsen K. 1992. "Increased risk of death from measles in children with a sibling of opposite sex in Senegal". British Medical Journal 304: $284-287$.

Prenter P. M. 1975. Splines and Variational Methods. New York: John Wiley \& Sons.

Reves R. 1985. "Declining fertility in England and Wales as a major cause of the twentieth century decline in mortality: The role of changing family size and age structure in infectious disease mortality in infancy". American Journal of Epidemiology 122: 112-126.

Rhodes C. J., Anderson R. M. 1996. "A scaling analysis of measles in epidemics in a small population". Philosophical Transactions of the Royal Society B 351: $1679-1688$. 


\section{Appendix}

Table 1

Estimated death rates from measles for: a) 0 to 14 year olds; b) 0 to 1 year olds; c) 1 to 4 year olds and; d) 5 to 14 year olds by sex and region,

New France 1714 and 1715.

a) 0 to 14 year olds

\begin{tabular}{|c|c|c|c|c|c|}
\hline & ${ }_{15} m_{0}$ & ${ }_{15} \boldsymbol{m}_{0 \text { (other) }}$ & ${ }_{15} m_{0(\text { measles })}$ & C.I (measles) $_{\text {(m) }}$ & $\begin{array}{c}\text { Measles } \\
\text { Deaths }(\%)\end{array}$ \\
\hline Colony & 88.7 & 35.8 & 52.8 & $(47.6-57.2)$ & 59.6 \\
\hline \multicolumn{6}{|l|}{$\underline{\operatorname{Sex}}$} \\
\hline Males & 86.4 & 37.0 & 49.4 & $(43.3-56.4)$ & 57.2 \\
\hline Females & 90.6 & 35.5 & 55.1 & $(48.4-62.7)$ & 60.8 \\
\hline \multicolumn{6}{|l|}{ Region } \\
\hline West & 74.0 & 38.6 & 35.4 & $(29.4-42.6)$ & 47.8 \\
\hline Central & 52.6 & 30.2 & 22.4 & $(15.7-32.1)$ & 42.6 \\
\hline East & 111.3 & 35.6 & 75.7 & $(67.8-84.5)$ & 68.0 \\
\hline \multicolumn{6}{|l|}{$\underline{\text { Urban }}$} \\
\hline Montreal & 87.8 & 42.4 & 45.4 & $(35.3-58.4)$ & 51.7 \\
\hline Quebec City & 129.0 & 38.3 & 90.8 & $(74.8-110.1)$ & 70.3 \\
\hline \multicolumn{6}{|l|}{$\underline{\text { Rural }}$} \\
\hline West & 63.9 & 35.8 & 28.1 & $(21.3-37.0)$ & 43.9 \\
\hline East & 104.7 & 34.5 & 70.1 & $(61.3-80.2)$ & 67.0 \\
\hline
\end{tabular}




\section{Appendix (continued)}

\section{b) 0 to 1 year olds}

\begin{tabular}{|c|c|c|c|c|c|}
\hline & $q_{0}$ & $q_{0(o t h e r)}$ & $q_{0 \text { (measles) }}$ & C.I. (measles) $_{\text {(m) }}$ & $\begin{array}{c}\text { Measles } \\
\text { Deaths }(\%)\end{array}$ \\
\hline Colony & 405.2 & 230.0 & 175.3 & $(150.9-199.7)$ & 43.2 \\
\hline \multicolumn{6}{|l|}{$\underline{\operatorname{Sex}}$} \\
\hline Males & 395.6 & 233.4 & 162.2 & (129.8-194.6) & 41.0 \\
\hline Females & 416.4 & 226.0 & 190.4 & $(153.5-227.3)$ & 45.7 \\
\hline \multicolumn{6}{|l|}{$\underline{\text { Region }}$} \\
\hline West & 433.6 & 261.5 & 172.1 & $(131.8-212.4)$ & 39.7 \\
\hline Central & 226.2 & 177.7 & 48.5 & $(12.6-84.5)$ & 21.5 \\
\hline East & 431.5 & 219.9 & 211.5 & $(174.4-248.6)$ & 49.0 \\
\hline \multicolumn{6}{|l|}{$\underline{\text { Urban }}$} \\
\hline Montreal & 482.1 & 284.2 & 197.9 & $(132.6-263.2)$ & 41.0 \\
\hline Quebec City & 414.4 & 220.1 & 194.3 & $(125.0-263.5)$ & 46.9 \\
\hline \multicolumn{6}{|l|}{ Rural } \\
\hline West & 398.8 & 244.7 & 154.1 & $(103.2-205.0)$ & 38.6 \\
\hline East & 437.8 & 219.9 & 217.8 & $(174.0-261.7)$ & 49.8 \\
\hline
\end{tabular}




\section{Appendix (continued)}

c) 1 to 4 year olds

\begin{tabular}{|c|c|c|c|c|c|}
\hline & ${ }_{4} m_{1}$ & ${ }_{4} \boldsymbol{m}_{1(\mathrm{other})}$ & ${ }_{4} \boldsymbol{m}_{1 \text { (measles) }}$ & C.I (measles) $_{\text {(n) }}$ & $\begin{array}{c}\text { Measles } \\
\text { Deaths }(\%)\end{array}$ \\
\hline Colony & 111.0 & 24.0 & 87.0 & $(76.2-99.3)$ & 78.4 \\
\hline \multicolumn{6}{|l|}{$\underline{\operatorname{Sex}}$} \\
\hline Males & 112.1 & 22.7 & 89.4 & $(74.4-107.4)$ & 79.8 \\
\hline Females & 109.9 & 26.3 & 83.5 & $(68.9-101.3)$ & 76.0 \\
\hline \multicolumn{6}{|l|}{$\underline{\text { Region }}$} \\
\hline West & 77.5 & 22.9 & 54.6 & $(41.3-72.2)$ & 70.5 \\
\hline Central & 73.4 & 25.0 & 48.4 & $(30.9-75.7)$ & 65.9 \\
\hline East & 148.1 & 24.5 & 123.6 & $(105.3-145.0)$ & 83.4 \\
\hline \multicolumn{6}{|l|}{ Urban } \\
\hline Montreal & 100.6 & 23.8 & 76.8 & $(53.1-111.0)$ & 76.4 \\
\hline Quebec City & 212.2 & 30.4 & 181.8 & $(141.4-233.7)$ & 85.7 \\
\hline \multicolumn{6}{|l|}{$\underline{\text { Rural }}$} \\
\hline West & 61.7 & 22.3 & 39.4 & $(25.7-60.4)$ & 63.9 \\
\hline East & 123.8 & 22.3 & 101.5 & $(82.5-124.9)$ & 82.0 \\
\hline
\end{tabular}




\section{Appendix (continued)}

d) 5 to 14 year olds

\begin{tabular}{|c|c|c|c|c|c|}
\hline & ${ }_{10} m_{5}$ & ${ }_{10} m_{5(o t h e r)}$ & ${ }_{10} \boldsymbol{m}_{5 \text { (measles) }}$ & C.I Imeasles) $_{\text {(m) }}$ & $\begin{array}{l}\text { Measles } \\
\text { Deaths }(\%)\end{array}$ \\
\hline Colony & 20.6 & 7.2 & 13.3 & $(11.5-18.1)$ & 64.8 \\
\hline \multicolumn{6}{|l|}{$\underline{\operatorname{Sex}}$} \\
\hline Males & 16.4 & 7.3 & 9.1 & $(6.1-13.6)$ & 55.7 \\
\hline Females & 25.0 & 7.2 & 17.8 & $(13.3-23.8)$ & 71.1 \\
\hline \multicolumn{6}{|l|}{ Region } \\
\hline West & 8.7 & 6.6 & 2.1 & $(0.8-5.6)$ & 24.4 \\
\hline Central & 21.2 & 9.3 & 12.0 & $(6.4-22.6)$ & 56.4 \\
\hline East & 33.3 & 6.5 & 26.7 & $(21.0-34.0)$ & 80.4 \\
\hline \multicolumn{6}{|l|}{ Urban } \\
\hline Montreal & 13.3 & 8.5 & 4.8 & $(1.8-12.9)$ & 36.4 \\
\hline Quebec City & 34.0 & 8.3 & 25.7 & $(16.1-41.2)$ & 75.6 \\
\hline \multicolumn{6}{|l|}{$\underline{\text { Rural }}$} \\
\hline West & 5.1 & 5.1 & - & - & - \\
\hline East & 33.0 & 5.9 & 27.1 & $(20.5-35.8)$ & 82.2 \\
\hline
\end{tabular}

